\title{
Article \\ Co-Doped Magnesium Oxychloride Composites with Unique Flexural Strength for Construction Use
}

\author{
Anna-Marie Lauermannová ${ }^{1}{ }^{\circledR}$, Ondřej Jankovský $^{1}{ }^{\circledR}$, Michal Lojka ${ }^{1}$, Ivana Faltysová ${ }^{1}$, Julie Slámová ${ }^{1}$,

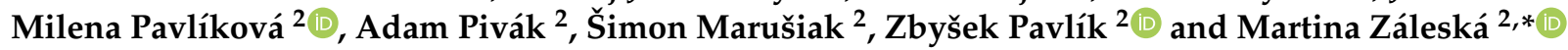 \\ 1 Department of Inorganic Chemistry, Faculty of Chemical Technology, University of Chemistry and \\ Technology, Technická 5, 16628 Prague, Czech Republic; Anna-Marie.Lauermannova@vscht.cz (A.-M.L.); \\ ondrej.jankovsky@vscht.cz (O.J.); michal.lojka@vscht.cz (M.L.); ivana.faltysova@vscht.cz (I.F.); \\ Julie.Slamova@vscht.cz (J.S.) \\ 2 Department of Materials Engineering and Chemistry, Faculty of Civil Engineering, Czech Technical \\ University in Prague, Thákurova 7, 16629 Prague, Czech Republic; milena.pavlikova@fsv.cvut.cz (M.P.); \\ adam.pivak@fsv.cvut.cz (A.P.); simon.marusiak@fsv.cvut.cz (Š.M.); pavlikz@fsv.cvut.cz (Z.P.) \\ * Correspondence: martina.zaleska@fsv.cvut.cz; Tel.: +420-224-354-688
}

\section{check for} updates

Citation: Lauermannová, A.-M.; Jankovský, O.; Lojka, M.; Faltysová, I.; Slámová, J.; Pavlíková, M.; Pivák, A.; Marušiak, Š.; Pavlík, Z.; Záleská, M. Co-Doped Magnesium Oxychloride Composites with Unique Flexural Strength for Construction Use. Materials 2022, 15, 604. https://doi.org/10.3390/ ma15020604

Academic Editor: Polina P. Kuzhir

Received: 8 December 2021

Accepted: 12 January 2022

Published: 14 January 2022

Publisher's Note: MDPI stays neutral with regard to jurisdictional claims in published maps and institutional affiliations.

Copyright: (c) 2022 by the authors. Licensee MDPI, Basel, Switzerland. This article is an open access article distributed under the terms and conditions of the Creative Commons Attribution (CC BY) license (https:// creativecommons.org/licenses/by/ $4.0 /)$.

\begin{abstract}
In this study, the combined effect of graphene oxide (GO) and oxidized multi-walled carbon nanotubes (OMWCNTs) on material properties of the magnesium oxychloride (MOC) phase 5 was analyzed. The selected carbon-based nanoadditives were used in small content in order to obtain higher values of mechanical parameters and higher water resistance while maintaining acceptable price of the final composites. Two sets of samples containing either $0.1 \mathrm{wt}$. \% or $0.2 \mathrm{wt}$. \% of both nanoadditives were prepared, in addition to a set of reference samples without additives. Samples were characterized by X-ray diffraction, scanning electron microscopy, Fourier-transform infrared spectroscopy, and energy dispersive spectroscopy, which were used to obtain the basic information on the phase and chemical composition, as well as the microstructure and morphology. Basic macro- and micro-structural parameters were studied in order to determine the effect of the nanoadditives on the open porosity, bulk and specific density. In addition, the mechanical, hygric and thermal parameters of the prepared nano-doped composites were acquired and compared to the reference sample. An enhancement of all the mentioned types of parameters was observed. This can be assigned to the drop in porosity when GO and OMWCNTs were used. This research shows a pathway of increasing the water resistance of MOC-based composites, which is an important step in the development of the new generation of construction materials.
\end{abstract}

Keywords: co-doped magnesium oxychloride cement; graphene oxide; oxidized MWCNTs; mechanical and physical parameters; microstructure; morphology and phase composition

\section{Introduction}

The recent advances in the research of the magnesium oxychloride cement (MOC) [1,2] show a promising direction in the field of alternative construction materials. As nonhydraulic binder prepared from light-burnt magnesia, MOC is usually considered as an environmentally sustainable and energy efficient construction material [3]. The material itself provides high values of compressive and flexural strength [4,5]; it is fireproof [6] and it has very short setting time [7]. Its ability to bond a wide range of additives makes it possible to enhance its properties by using various fillers and to create materials with very specific mechanical, physical, chemical and functional properties, which are applicable in many branches of the construction industry. It is possible to use great volumes of secondary fillers, such as diatomite [8], fly ash [9,10], glass powder [11], wood aggregates [12,13], lunar regolith simulant [14] or others [15], in order to create an eco-friendly material, while maintaining the high mechanical strength and stiffness. 
The production of MOC is quite simple and depending on the molar ratio of the raw materials and the conditions of the synthetic procedure, such as temperature, a variety of compounds in the system $\mathrm{MgO}-\mathrm{MgCl}_{2}-\mathrm{H}_{2} \mathrm{O}$ can be synthesized [16,17]. The most common and used phase of this system is MOC phase 5 (also known as MOC 5-1-8), whose formula is $5 \mathrm{Mg}(\mathrm{OH})_{2} \cdot \mathrm{MgCl}_{2} \cdot \mathrm{H}_{2} \mathrm{O}$. This phase crystallizes in the form of needle-shaped whiskers [18]. The interlocking of these crystals is one of the possible causes of the high strength of the binder [19]. The properties of MOC are also influenced by its ability to absorb $\mathrm{CO}_{2}$ from the atmosphere $[20,21]$ which results in the formation of magnesium carbonate phases on the surface of MOC.

The main issue of MOC is its low water resistance [22,23]. The decomposition of MOC in the water environment and the reaction of the present phases with water which forms brucite have been previously described in the literature [24,25]. During this process, the mechanical strength decreases rapidly and leads to leaching of magnesium chloride, which creates a corrosive environment. Therefore, such material is not applicable in combination with steel reinforcement [26,27]; alternative reinforcing materials must be researched [28]. The issue of the low water resistance was previously studied by many researchers and various approaches have been suggested. Li et al. [29] have described the process of using phosphoric acid and soluble phosphates in the amount of $0.5-1.0 \mathrm{wt}$ \% of the MOC phase, resulting in a very significant increase in the water resistance. Similarly, citric acid [30] and tartaric acid [31,32] also showed improvement on the water resistance of MOC. The use of fly ash as an additive for increasing the water resistance was described by Wu et al. [33]; however, the influence of the dosage of the fly ash on the mechanical properties of the prepared composites was negative and quite significant. Another approach was used by He et al. [34], who suggested the use of incinerated sewage sludge ash. The disadvantage of this method is in the varying composition of the ash in different locations and, therefore, different effects on the water resistance. A possible solution to this problem lies in the area of the carbon-based nanomaterials.

The general use of carbon-based nanomaterials in the construction composites is based on the addition of a small amount of the nanomaterial into the matrix while obtaining large enhancement of the material properties. This originates in the extraordinary properties of the C-based nanomaterials, namely their high mechanical strength [35], great electrical and thermal conductivity [36], and outstanding optical properties [37]. Graphene and its derivatives belong to the group of 2D carbon nanomaterials. The functionalization of graphene and formation of its derivative has been thoroughly studied in the past years. It can be modified with sulfur, fluorine, boron, nitrogen and other elements [38-43]. The multi-walled carbon nanotubes (MWCNTs) and their derivatives are representatives of the $1 \mathrm{D}$ group of carbon nanomaterials. Analogically to graphene, MWCNTs can be modified to create many derivatives with various functional groups [44-48].

The use of graphene and carbon nanotubes in ordinary construction composites is limited by their difficult dispersion in water, which is caused by their hydrophobicity [49]. The hydrophobic nature of these materials can be affected by their functionalization, and therefore the dispersion of such materials in the composite matrix is much easier. The process of functionalization of these nanoadditives is usually based on their reaction with strong acids and formation of their oxidized analogues [50,51]. The oxidized analogues contain hydroxyl $(-\mathrm{OH})$, carboxyl $(-\mathrm{COOH})$ and other groups, which can react with the matrix itself and contribute to the mechanical properties of the final composite [52,53].

The use of carbon-based nanoadditives in MOC as a mechanical and physical propertiesenhancement agent has been previously described in the literature. It has been proven that a very small amount of graphene $(\mathrm{G})$, graphene oxide $(\mathrm{GO})$, multi-walled carbon nanotubes (MWCNTs) or their oxidized analogues (OMWCNTs), can improve the mechanical and physical properties of the MOC matrix [54,55].

Using GO and OMWCNTs as additives in MOC should result in the formation of various types of interactions between their atoms and the magnesium ions in the MOC matrix. This is caused by the reaction between such ions and the oxygen-containing groups 
of the oxidized nanoadditives [56]. In the previous studies, the interactions between magnesium ions and GO have been divided into two groups: (1) bridging the edges of the sheets through carboxylate chelates to the metal and (2) intercalating between the basal planes through either weak alkoxide or dative bonds from carbonyl and hydroxyl groups; however, it has been shown that the latter type are weak and can be removed by water rinsing. Moreover, as GO contains reactive epoxy groups, its exposure to Lewis acidic divalent metal ions such as $\mathrm{Mg}^{2+}$ may lead to ring-opening of such groups. During this process, new types of C-O bonds may form $[57,58]$. The interactions between OMWCNTs and magnesium ions are mainly chemical; however, the electrostatic interactions and sorption-precipitation interactions also occur at a lower rate. The origin of such interaction is caused by the nature of the oxygen-containing groups, which induce negative charge on the OMWCNT's surface, resulting in donation of the single pair of electrons from the oxygen to the magnesium ions [59].

In this study, a combined influence of graphene oxide and OMWCNTs on the properties of MOC matrix was evaluated. The novelty of the paper lies in fact that the effect of co-doping of MOC matrix by a blend of 1-D and 2-D oxidized carbon-based nanoadditives has not been analyzed yet, although it can bring potential improvement in technical and functional parameters of multi-scale MOC composites for construction use. Based on the required mechanical and material properties, according amounts of both nanoadditives were chosen and used for the preparation of a novel composite based on reactive magnesia. The basic micro- and macro-structural parameters, as well as the mechanical, hygric and thermal properties, were studied in order to obtain a complex insight into the problems of the nano-doping of MOC with oxidized forms of carbon-based nanoadditives.

\section{Materials and Methods}

The studied composites were prepared using $\mathrm{MgCl}_{2} \cdot 6 \mathrm{H}_{2} \mathrm{O}$ (>99\%, Lach-Ner Ltd., Neratovice, Czech Republic), light MgO powder (>98\%, Penta Ltd., Prague, Czech Republic), graphene oxide (lateral size $0.2-10 \mu \mathrm{m}$, thickness $2 \mathrm{~nm}$, ACS Material, LLC., Pasadena, CA, USA) and functionalized multi-walled carbon nanotubes (TNIMC8 with declared purity $>95$ wt. \%, length $<10 \mu \mathrm{m}$, TimesNano, Chengdu, China). Both carbon-based nanomaterials were analyzed before their addition to MOC-based composites. The BET specific surface was $47.1 \mathrm{~m}^{2} \cdot \mathrm{g}^{-1}$ for graphene oxide and $76.9 \mathrm{~m}^{2} \cdot \mathrm{g}^{-1}$ for OMWCNTs.

Micrographs of OMWCNTs and GO can be seen in Figure 1.

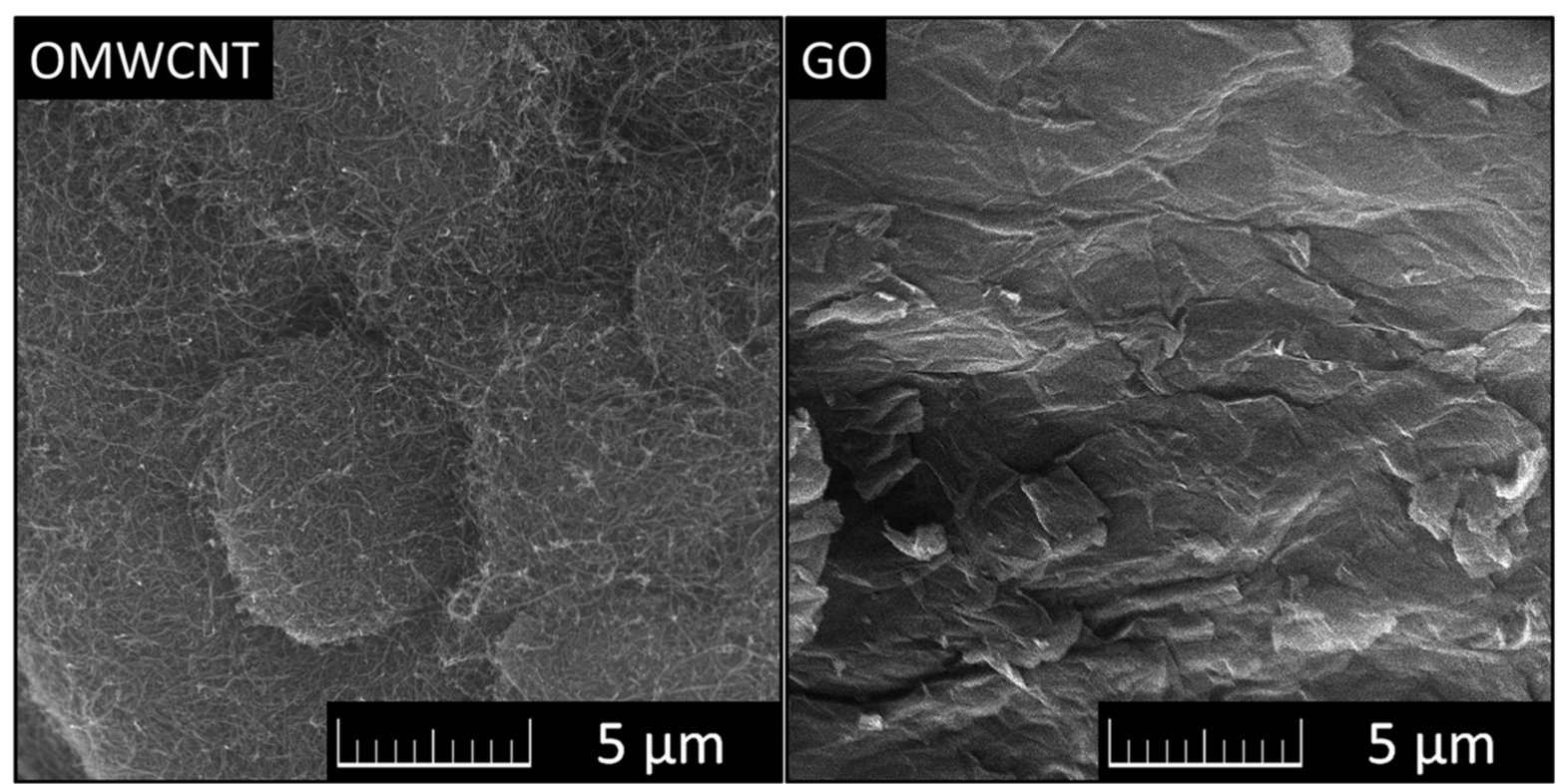

Figure 1. Micrographs of OMWCNTs (left) and GO (right) observed using SEM. 
Elemental composition of both nanoadditives is shown in Table 1.

Table 1. Elemental composition of OMWCNT and GO observed using EDS (in wt. \%).

\begin{tabular}{cccccc}
\hline EDS wt. $\%$ & C & O & S & Ni & Al \\
\hline OMWCNT & 96.2 & 2.6 & - & 0.8 & 0.4 \\
GO & 65.7 & 32.6 & 1.7 & - & - \\
\hline
\end{tabular}

The obtained microstructure of OMWCNTs and Graphene Oxide (GO) is shown in Figure 2.

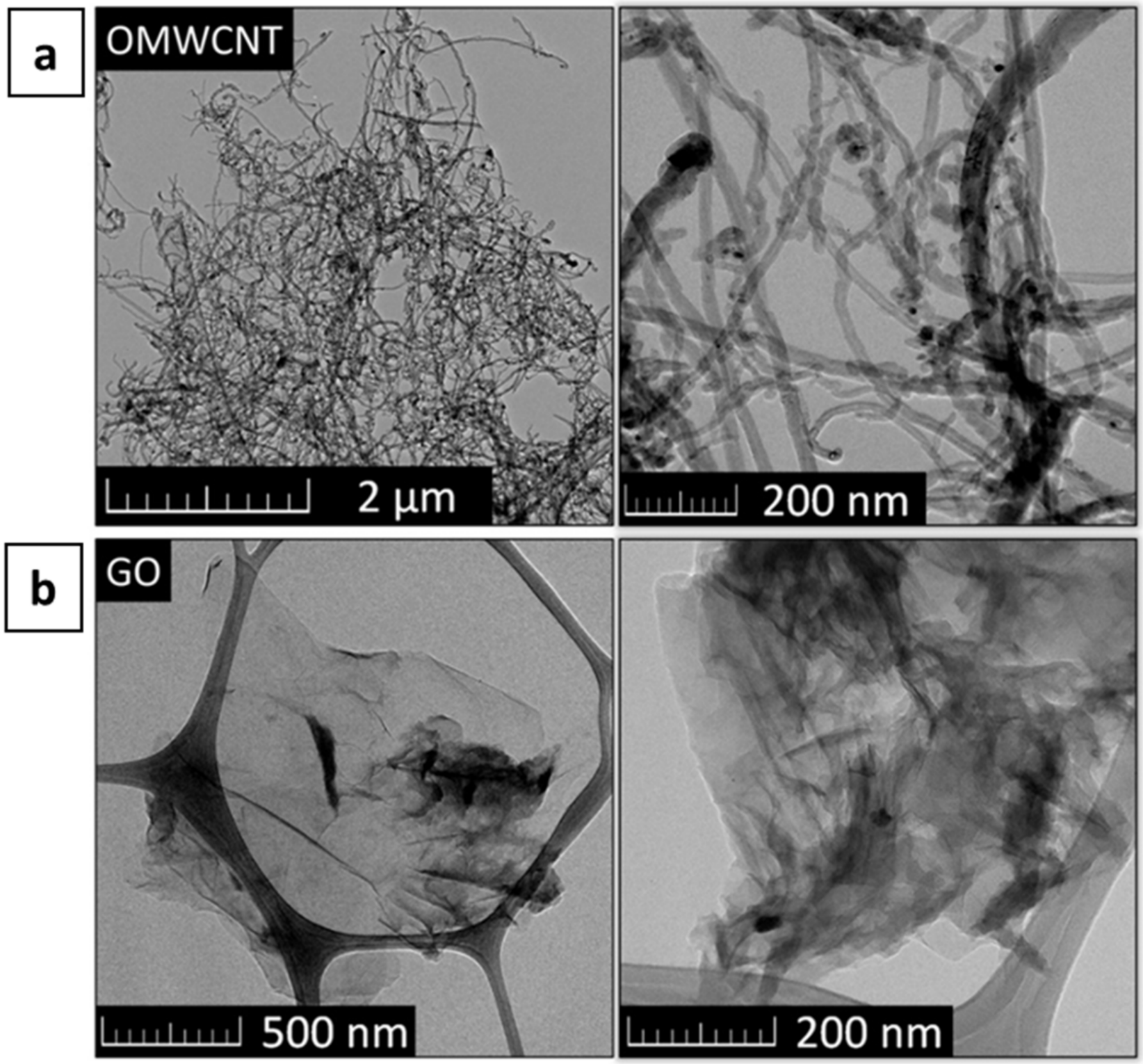

Figure 2. TEM image of (a) OMWCNTs and (b) GO.

The composition of the prepared samples is introduced in Table 2. In the formulation of the mixtures, $\mathrm{MgO}$ was added in excess, its unreacted part served as filler. MOC-REF is a reference mixture without nanoadditives. In samples marked GO-OMWCNT, the graphene oxide (GO) and oxidized multi-walled carbon nanotubes (OMWCNTs) were used in the amount of $0.1 \mathrm{wt}$. \% (MOC-GO-OMWCNT-0.1) and $0.2 \mathrm{wt}$ \% (MOC-GO-OMWCNT-0.2) of the whole MOC mixture. 
Table 2. Mixture proportion: dosage of the particular components.

\begin{tabular}{cccccc}
\hline \multirow{2}{*}{ Mixture/Composite } & \multicolumn{3}{c}{ Mass $\mathbf{( g )}$} \\
\cline { 2 - 6 } & $\mathbf{M g O}$ & $\mathbf{M g C l}_{\mathbf{2}} \cdot \mathbf{6} \mathbf{H}_{\mathbf{2}} \mathbf{O}$ & $\mathbf{H}_{\mathbf{2}} \mathbf{O}$ & $\mathbf{G O}$ & $\mathbf{O M W C N T}$ \\
\hline MOC-REF & 553.6 & 399.0 & 247.3 & - & 1.2 \\
MOC-GO-OMWCNT-0.1 & 552.5 & 398.2 & 246.9 & 2.4 & 2.4 \\
\hline
\end{tabular}

$\mathrm{MgCl}_{2} \cdot 6 \mathrm{H}_{2} \mathrm{O}$ was dissolved in tap water. GO and OMWCNTs were dosed and dispersed together in the part of the prepared $\mathrm{MgCl}_{2}$ water solution using a homogenizer UltraTurrax T-18 (IKA, Staufen im Breisgau, Germany). This first step of homogenization took $5 \mathrm{~min}$ and was realized at 11,000 rpm. The obtained suspension was transferred to a planetary type mixer (ELE) with the rest of $\mathrm{MgCl}_{2}$ solution, and the $\mathrm{MgO}$ powder was added. The second homogenization in ELE took $5 \mathrm{~min}$. The fresh mixtures were then cast into steel molds with dimensions of $40 \mathrm{~mm} \times 40 \mathrm{~mm} \times 160 \mathrm{~mm}$, unmolded after $24 \mathrm{~h}$, and cured in the air atmosphere laboratory at temperatures of $(23 \pm 2){ }^{\circ} \mathrm{C}$ and relative humidity of $(50 \pm 5) \%$. After 27 days, the samples were submitted to the particular tests.

For the fresh mixtures, rheological parameters such as dynamic viscosity $\eta(\mathrm{Pa} \cdot \mathrm{s})$ and shear stress $\tau(\mathrm{Pa})$ as functions of velocity gradient were measured in order to document possible effect off MOC co-doping on the changes of its workability. The measurement itself was performed by the use of the rotation viscometer HAAKE Viscometer E (Thermo Fisher Scientific, Waltham, MA, USA) equipped with a rotary spindle R3 type.

X-ray powder diffraction (XRD) was carried out using a Bruker D2 Phaser (Bruker AXS GmbH, Karlsruhe, Germany), a powder diffractometer with Bragg-Brentano geometry, applying $\mathrm{CuK} \alpha$ radiation $(\lambda=0.15418 \mathrm{~nm}, \mathrm{U}=30 \mathrm{kV}, \mathrm{I}=10 \mathrm{~mA})$ and $5 \mathrm{rpm}$ rotation. The step size was set to of $0.02025^{\circ}(2 \theta)$ and the overall data were acquired in the angular range of $5^{\circ}-80^{\circ}$. To evaluate the obtained data, X'Pert HighScore Plus software (2017, PANalytical, Almelo, The Netherlands) was used.

To study the surface morphology and microstructure of the prepared samples, scanning electron microscopy (SEM) was used (Tescan MAIA3, TESCAN Brno, s.r.o., Brno, Czech Republic).

The elemental composition and mapping were characterized using an energy-dispersive spectroscopy (EDS) analyzer (X-Max150, Oxford Instruments, High Wycombe, UK) with a 20-mm ${ }^{2}$ SDD (silicon drift detector) detector and AZtecEnergy software (Oxford instruments, High Wycombe, UK). The sample was set on a carbon conductive tape to ensure the conductivity of the experiments. For both SEM and SEM-EDS analysis, the electron beam was set to $10 \mathrm{kV}$.

To study the used carbon-based nanomaterials, HR-TEM was performed using an EFTEM Jeol 2200 FS microscope (Jeol, Tokyo, Japan). A $200 \mathrm{keV}$ acceleration voltage was used for the measurement. The sample preparation was attained by drop-casting the suspension ( $1 \mathrm{mg} \cdot \mathrm{mL}^{-1}$ in isopropyl alcohol) on a TEM grid ( $\mathrm{Cu} ; 200 \mathrm{mesh}$; Formvar/carbon) and then drying in a vacuum dryer at $25^{\circ} \mathrm{C}$ and $\mathrm{p} / \mathrm{p} 0=0.2$.

The BET specific surface was measured using a sorption analyzer NOVAtouch LX2 (Quantachrome Instruments, Boynton Beach, Florida, USA). The sample was outgassed for $10 \mathrm{~h}$ at $100{ }^{\circ} \mathrm{C}$ under high vacuum. A nitrogen-cooled (77 K) detector was used for the evaluation of the results using BET (Brunauer, Emmett and Teller) and Kelvin equations. The Quantachrome software was used for evaluation of measured data and to recalculate the measured value to $\mathrm{m}^{2}$ per $1 \mathrm{~g}$.

To verify the distribution and presence of applied oxidized nanoadditives and to reveal the main precipitated phases and bonds among the chemical forming the hardened structure of the researched composites, the MIR (mid-infrared) spectra were collected using ATR (attenuated total reflection) technique. The MIR spectra were obtained after 32 scans that were conducted using the FT-IR spectrometer Nicolet 6700 (Thermo Fisher Scientific, Waltham, MA, USA), which operates with spectral resolution $4 \mathrm{~cm}^{-1}$ at the spectral range 
$4000-400 \mathrm{~cm}^{-1}$. The analyzed samples were cut from the original prisms, dried in a vacuum drier and then mechanically crushed and homogenized with a ball grinder MM 400 (RETSCH, Haan, Germany). Finally, they were pulverized in an agate mortar.

The tests of the hardened composites were done for 28 days matured samples. The experimental campaign was proposed in such a way to evaluate the co-doping effect of the oxidized nanoadditives on the structural, mechanical, hygric, and thermal parameters on MOC-based matrix. For each composite mixture, at least 5 samples were subjected to the particular tests. To measure the dry bulk density, the casted prisms $40 \mathrm{~mm} \times 40 \mathrm{~mm} \times 160 \mathrm{~mm}$ were dried in a vacuum drier at $50{ }^{\circ} \mathrm{C}$ until their constant mass was achieved. The dry bulk density $\rho_{\mathrm{b}}\left(\mathrm{kg} \cdot \mathrm{m}^{-3}\right)$ was then measured as prescribed in the EN 1015-10 [60]. The fragments extracted from the inner part of the crushed prisms were analyzed in a helium pycnometer Pycnomatic ATC (Porotec, Hofheim, Germany) to determine their specific density $\rho_{\mathrm{s}}\left(\mathrm{kg} \cdot \mathrm{m}^{-3}\right)$. The total open porosity was calculated from the bulk density and specific density values [61]. The composites microstructure was studied on a mercury porosimetry principle using porosimeters of Pascal series, Pascal 140 and Pascal 440 (Thermo Fisher Scientific, Waltham, MA, USA). The pore size was evaluated from the mercury pressure using the Washburn-Laplace equation and the cylindrical capillaries were assumed. The investigated parameters were pore size distribution curves, total pore volume, average and modal pore diameter and pore surface area. The dry samples mass in microstructural analysis was about $2 \mathrm{~g}$. The compressive strength $f_{\mathrm{c}}(\mathrm{MPa})$, flexural strength $f_{\mathrm{f}}(\mathrm{MPa})$, and the dynamic modulus of elasticity $E_{\mathrm{d}}(\mathrm{GPa})$ were the tested mechanical parameters. The mechanical strength tests were performed in compliance with the EN 1015-11 [62]. The flexural strength was measured on the casted prisms in a three-point bending strength test arrangement. On the rest of broken prisms, the compressive strength was assessed. The loaded cross section in the uniaxial strength tests was $40 \times 40 \mathrm{~mm}^{2}$. The stiffness of MOC composites was characterized by the dynamic modulus of elasticity, which was tested by the Vikasonic apparatus (Schleinbinger Geräte, Buchbach, Germany) operating on a frequency of $54 \mathrm{kHz}$. The specimens were $40 \times 40 \times 160 \mathrm{~mm}$ prisms and were measured along their longitudinal axis. A capillary absorption test was used to evaluate the water transport and storage in the examined composites and to quantify the effect of nanoadditives usage on the deceleration and retardation of water ingress. The measured parameters were water absorption coefficient $A_{\mathrm{w}}\left(\mathrm{kg} \cdot \mathrm{m}^{-2} \cdot \mathrm{s}^{-1 / 2}\right), 24-\mathrm{h}$ water absorption $W\left(\mathrm{~kg} \cdot \mathrm{m}^{-2}\right)$, and 24-h water absorption $W_{\mathrm{a}}(\mathrm{wt} . \%)$. These were obtained in accordance with the EN 1015-18 [63]. The samples used in the water absorption experiment were prisms with a size of $40 \times 40 \times 160 \mathrm{~mm}$. As the nano-doping of the MOC matrix affects its porous structure, and thus heat transport and storage, thermal conductivity $\lambda$ $\left(\mathrm{W} \cdot \mathrm{m}^{-1} \cdot \mathrm{K}^{-1}\right)$, thermal diffusivity $a\left(\mathrm{~m}^{2} \cdot \mathrm{s}^{-1}\right)$, and volumetric heat capacity $c_{\mathrm{V}}\left(\mathrm{J} \cdot \mathrm{m}^{-3} \cdot \mathrm{K}^{-1}\right)$ of the matured samples were tested using a Hot Disk TPS 1500 (Hot Disk AB, Göteborg, Sweden) apparatus equipped with the Kapton-insulated sensor having a radius of $6.4 \mathrm{~mm}$. The temperature of the thermal parameters test was $(23 \pm 2)^{\circ} \mathrm{C}$. Before the measurement, the prismatic samples having a size of $40 \times 40 \times 50 \mathrm{~mm}$ were dried in a vacuum at $50{ }^{\circ} \mathrm{C}$. The used experimental techniques and conducted test are together with the expanded combined uncertainties of the particular investigated parameters summarized in Table 3. 
Table 3. The expanded combined uncertainties (ECU) of the applied testing methods.

\begin{tabular}{ccccc}
\hline Material Parameter & Symbol & Unit & ECU (\%) & Method/Standard \\
\hline Bulk density & $\rho_{\mathrm{b}}$ & $\left(\mathrm{kg} \cdot \mathrm{m}^{-3}\right)$ & 1.4 & EN 1015-10 \\
Specific density & $\rho_{\mathrm{s}}$ & $\left(\mathrm{kg} \cdot \mathrm{m}^{-3}\right)$ & 1.2 & Helium pycnometry \\
Total open porosity & $\Psi$ & $(-)$ & 2.0 & Gravimetry/pycnometry \\
Flexural strength & $f_{\mathrm{f}}$ & $(\mathrm{MPa})$ & 1.4 & EN 1015-11 \\
Compressive strength & $f_{\mathrm{c}}$ & $(\mathrm{MPa})$ & 1.4 & EN 1015-11 \\
Dynamic modulus of elasticity & $E_{\mathrm{d}}$ & $(\mathrm{GPa})$ & 2.3 & Ultrasonic pulse velocity \\
Water absorption coefficient & $A_{\mathrm{w}}$ & $\left(\mathrm{kg} \cdot \mathrm{m}^{-2} \mathrm{~s}^{-1 / 2}\right)$ & 2.3 & EN 1015-18 \\
24-h water absorption & $W$ & $\left(\mathrm{~kg} \cdot \mathrm{m}^{-2}\right)$ & 1.2 & EN 1015-18 \\
24-h water absorption & $W_{\mathrm{a}}$ & $(\mathrm{wt} . \%)$ & 1.2 & EN 1015-18 \\
Thermal conductivity & $\lambda$ & $\left(\mathrm{W} \cdot \mathrm{m}^{-1} \cdot \mathrm{K}^{-1}\right)$ & 2.3 & Hot disk \\
Thermal diffusivity & $a$ & $\left(\mathrm{~m}^{2} \cdot \mathrm{s}^{-1}\right)$ & 2.6 & Hot disk \\
Volumetric heat capacity & $c_{\mathrm{v}}$ & $\left(\mathrm{J} \cdot \mathrm{m}^{-3} \cdot \mathrm{K}^{-1}\right)$ & 2.6 & Hot disk \\
\hline
\end{tabular}

\section{Results and Discussion}

We prepared three sets of samples and we compared their properties. Samples were marked as MOC-REF (reference with no added carbon nanostructures), MOC-GOOMWCNT-0.1 (with 0.1 wt. \% of GO and 0.1 wt. \% of OMWCNT) and MOC-GOOMWCNT-0.2 (with 0.2 wt. \% of GO and 0.2 wt. \% of OMWCNT). The hardened specimens are presented in Figure 3.

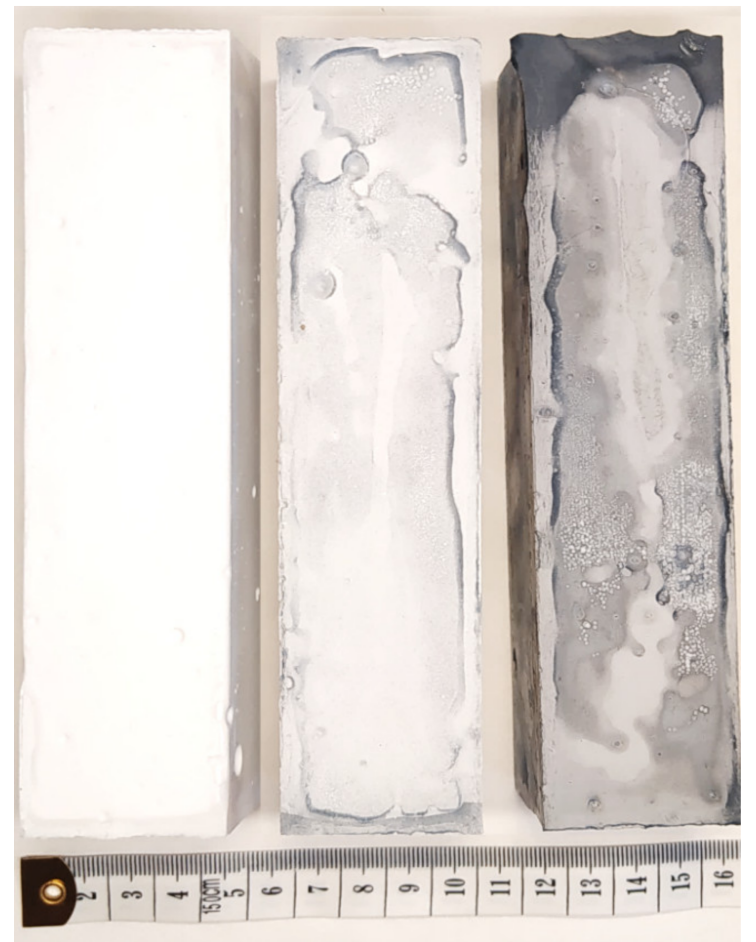

Figure 3. 28-days specimens: MOC-REF, MOC-GO-OMWCNT-0.1, MOC-GO-OMWCNT-0.2 (from left).

The effect of the application of nanoadditives on the rheology of fresh composites mixtures was studied using a rotation viscometer. The dynamic viscosity (dash lines) and the shear stress plotted in the dependence on the velocity gradient are graphed in Figure 4. As only minimum differences in investigated rheological parameters were recorded, the effect of the incorporation of GO and OMWCNTs can be considered as negligible, which enables one to design and develop multiscale composites with improved functional and technical properties. As used nanoadditives have no adverse effect on the workability 
of fresh composites, it is possible to incorporate different types of fillers, aggregates and reinforcing fibers in composite mixture that would bring other advanced parameters of the materials on nano-doped MOC basis.

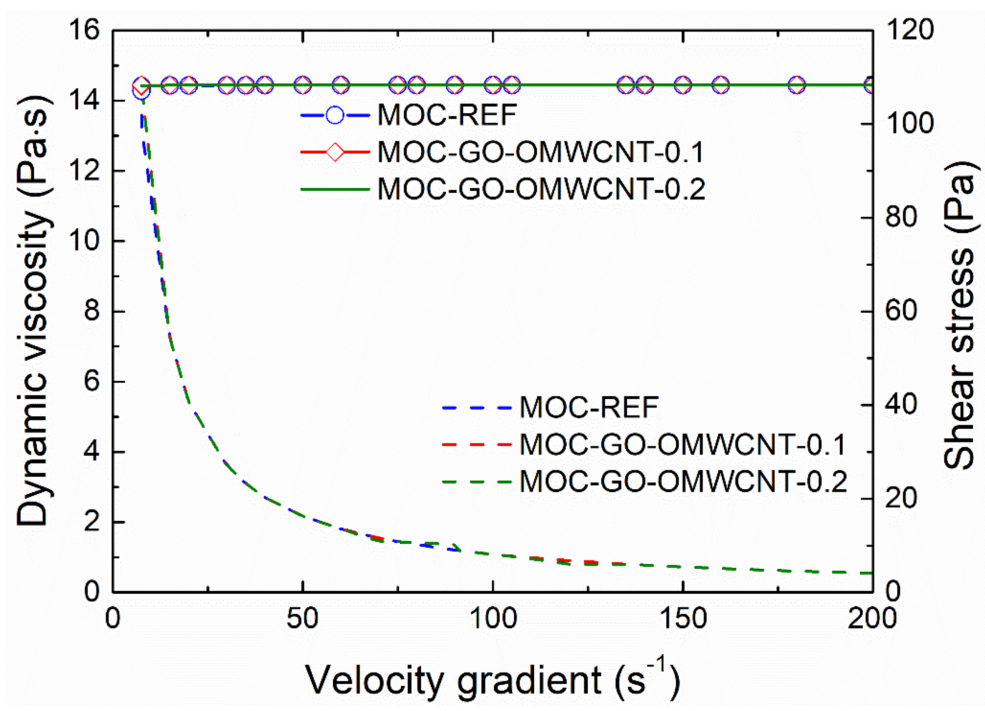

Figure 4. Dynamic viscosity and shear stress of fresh composite mixtures.

To confirm the phase composition of the hardened composites, XRD analysis was used. The diffraction patterns of the three types of samples (see Figure 5) are all similar due to the presence of the two required crystalline phases-MOC Phase 5 (ICDD 04-014-8836) with the main reflection at $2 \theta=11.9^{\circ}$ and $\mathrm{MgO}$ (ICDD 04-007-5693) with its characteristic reflection at $2 \theta=40.9^{\circ}$, which works as a filler in the samples. The carbon-based nanomaterials used as dopants are not visible in the diffraction patterns due to their low content.

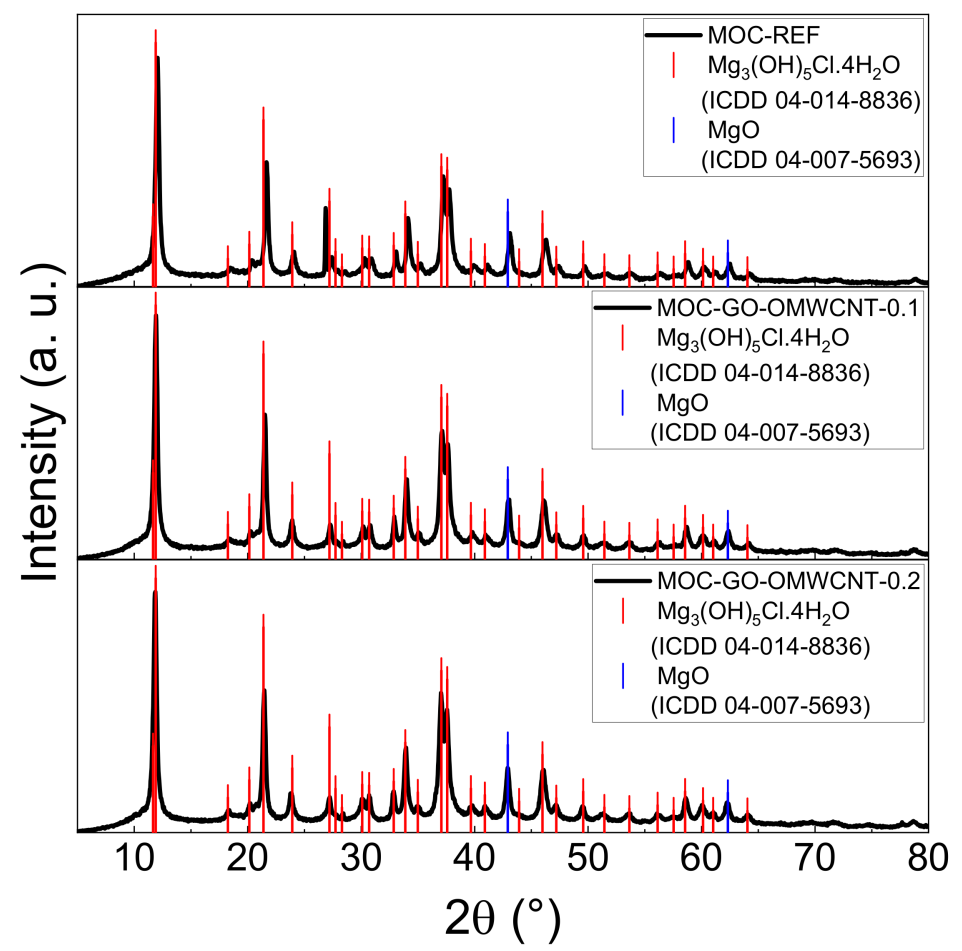

Figure 5. The XRD patterns of the samples MOC-REF (top), MOC-GO-OMWCNT-0.1 (middle) and MOC-GO-OMWCNT-0.2 (bottom). 
The SEM was used in order to study the morphology of the prepared set of samples. The micrographs show in Figure 6 show a compact structure of the samples without cracks. For the sample MOC-REF, the typical needle-shaped crystals were visible, especially in the area of air-bubbles which formed in the suspension during mixing. The presence of needle-shaped crystals in the samples containing GO and OMWCNTs was also confirmed; however, these crystals had less distinct shape with blurred edges and, overall, were shorter and wider than the ones of the reference sample.

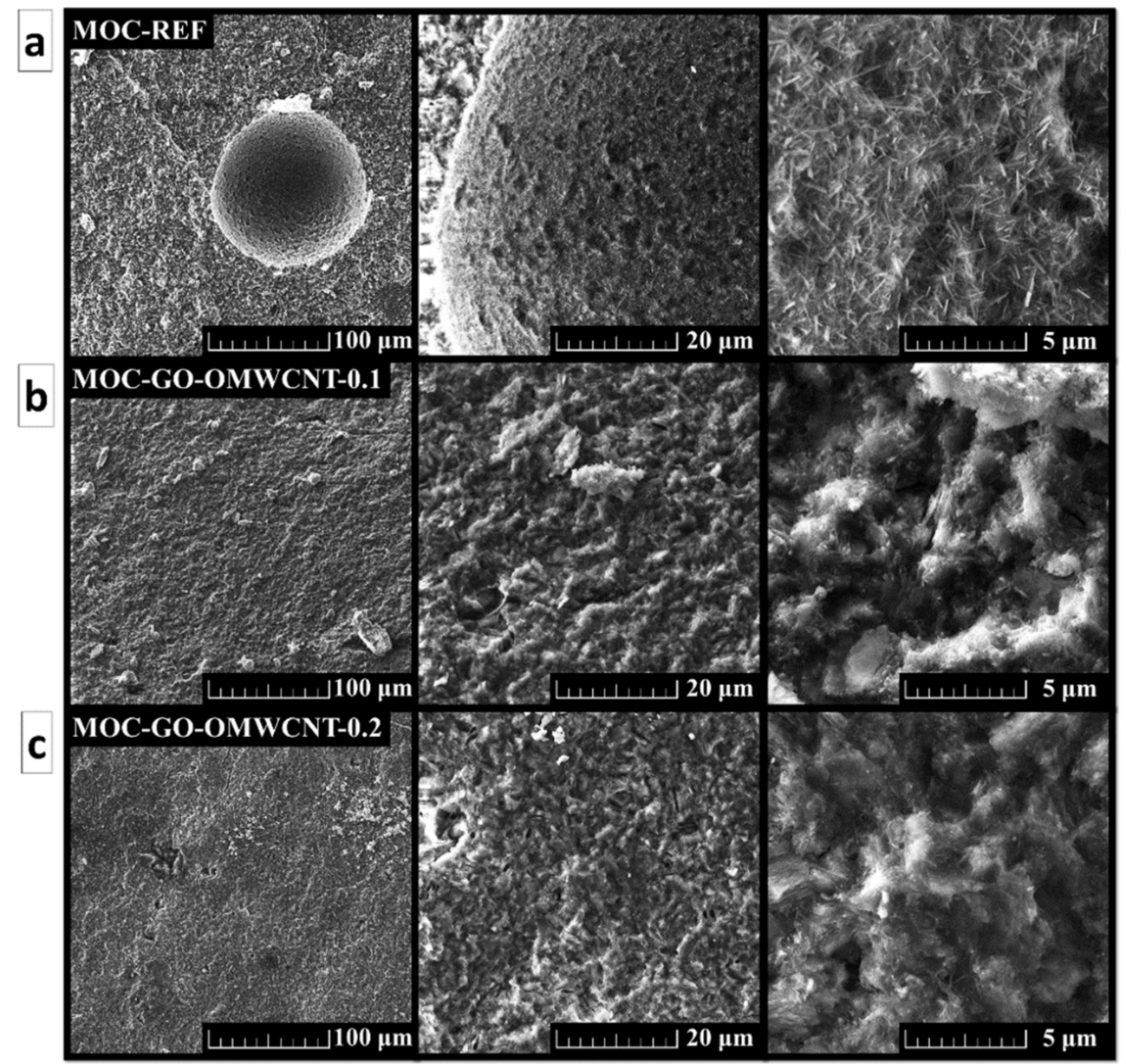

Figure 6. The SEM micrographs of (a) MOC-REF, (b) MOC-GO-OMWCNT-0.1 and (c) MOC-GOOMWCNT-0.2.

The elemental maps (Figure 7a) and the elemental composition in wt. \% (Figure 7b) of the prepared composites were provided by EDS. The elemental maps showed good dispersion of each element present in the samples. The quantitative part of the EDS analysis showed the content of each element for each sample. For the sample MOC-REF, the content of the elements was 50.0 wt. \% of $\mathrm{O}, 33.3 \mathrm{wt}$. \% of $\mathrm{Mg}, 11.6 \mathrm{wt}$. \% of $\mathrm{Cl}$ and $5.1 \mathrm{wt}$. \% of $\mathrm{C}$. The carbon was present probably due to the reaction of $\mathrm{MOC}$ with the atmospheric $\mathrm{CO}_{2}$, during which magnesium carbonate phases such as chlorartinite were formed. The sample MOC-GO-OMWCNT-0.1 contained 41.2 wt. \% of O, 38.5 wt. \% of Mg, 16.8 wt. \% of Cl and $3.5 \mathrm{wt}$. \% of C. The third sample, MOC-GO-OMWCNT-0.2, contained $45.7 \mathrm{wt}$. \% of $\mathrm{O}, 34.8$ wt. \% of $\mathrm{Mg}, 12.2$ wt. \% of $\mathrm{Cl}$ and 7.2 wt. \% of $\mathrm{C}$. The increase of the content of $\mathrm{C}$ is well visible between the samples containing $0.1 \mathrm{wt}$. \% of each dopant and the samples containing 0.2 wt. \% of GO and OMWCNTs. The increase also corresponded with the expected value. 
a

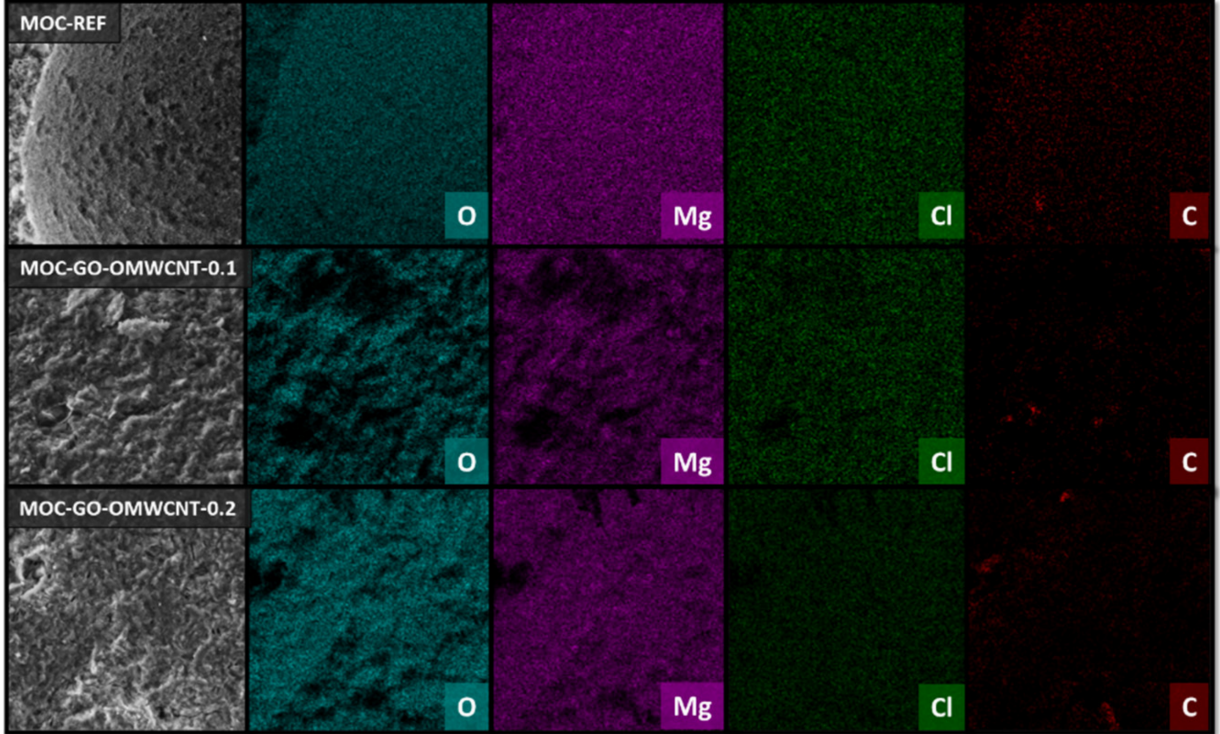

$50 \mu \mathrm{m}$
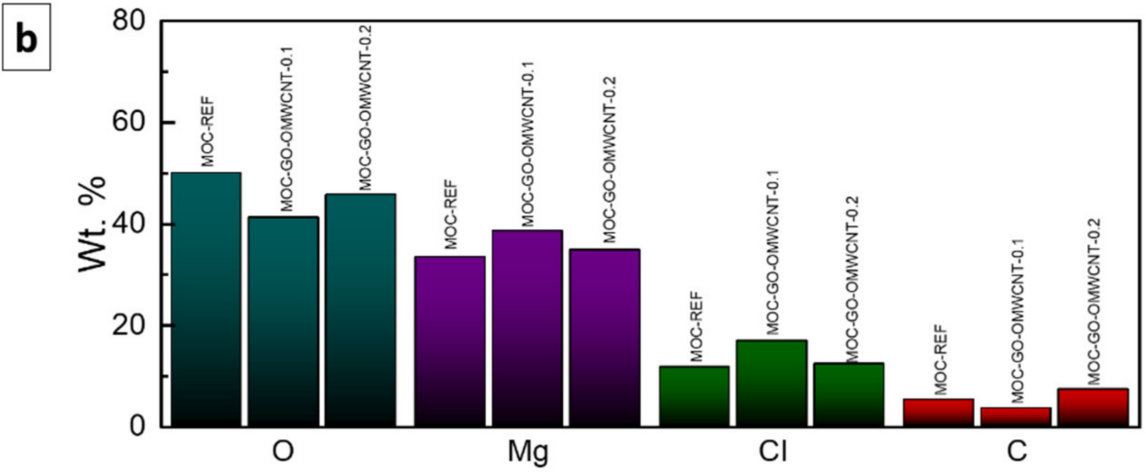

Figure 7. (a) The elemental maps and (b) the elemental composition (in wt. \%) of the samples MOC-REF, MOC-GO-OMWCNT-0.1 and MOC-GO-OMWCNT-0.2.

Figure 8 presents the collected MIR spectra of the analysed MOC composites. The assignment of the major absorption bands is summarized in Table 4. We can recognize characteristic bands corresponding to the basic vibrations of $\mathrm{H}_{2} \mathrm{O}$ and the lattice vibrations of $\mathrm{MgCl}_{2}$ and $\mathrm{Mg}(\mathrm{OH})_{2}$. The presence of the carbon nanotubes and graphene was significantly observed at $1607 \mathrm{~cm}^{-1}$, where the stretching vibration of $\mathrm{C}=\mathrm{C}$ bond in the MIR spectrum could be identified $[64,65]$. The rising calculated peak area confirmed the presence of graphene oxide and carbon nanotubes. Namely, the peak area of the $\mathrm{C}=\mathrm{C}$ bond stretching vibration was $0.093 ; 0.3168$ and 0.6073 in the case of MOC-REF, MOC-GO-OMCWNT-0.1, and MOC-GO-OMCWNT-0.2, respectively. This data corresponds with the composition of composites and their mechanical parameters; it is also in an agreement with the relative brucite amount, which is manifested at $3695 \mathrm{~cm}^{-1}$ as the stretching vibration of the $\mathrm{O}-\mathrm{H}$ group [66]. The content of brucite was mounted in the order MOC-GO-OMCWNT-0.2, MOC-GO-OMCWNT-0.1 and MOC-REF.

The spectral data presented as curves bear resemblance to each other; significant bands could be observed. In the range of $3300-3700 \mathrm{~cm}^{-1}$, the stretching vibrations $\mathrm{O}-\mathrm{H}$ bond could be identified. At $1644 \mathrm{~cm}^{-1}$ and $1149 \mathrm{~cm}^{-1}$, the band could be assigned to O-H bending vibrations in $\mathrm{MgCl}_{2} \cdot 8 \mathrm{H}_{2} \mathrm{O}$. The broad band at $1417-1446 \mathrm{~cm}^{-1}$ was coming from the bending vibrations of $\mathrm{O}-\mathrm{H}$ bonds in the hydroxyl group in $\mathrm{Mg}(\mathrm{OH})_{2}$ and the stretching vibration of $\mathrm{C}=\mathrm{O}$ bond in magnesite and chlorartinite [67]. In the range below $600 \mathrm{~cm}^{-1}$, the series of the bands could be attributed to the lattice vibrations of $\mathrm{Mg}-\mathrm{O} / \mathrm{Mg}-\mathrm{Cl}$ bonds and the stretching vibration of the $\mathrm{Mg}-\mathrm{O}$ cubic structure. 


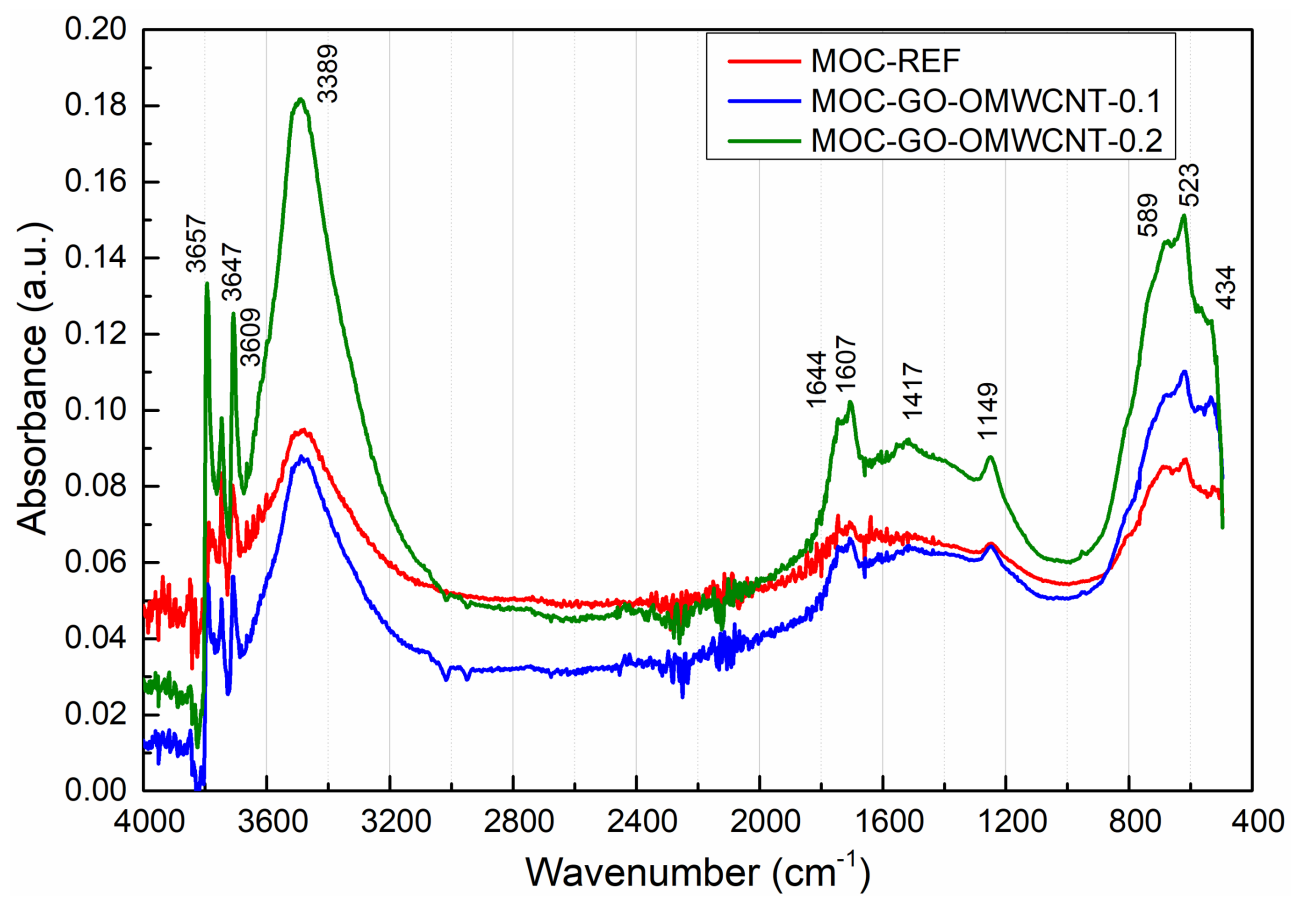

Figure 8. The collected MIR spectra of tested composites in the range of $400-4000 \mathrm{~cm}^{-1}$.

Table 4. Assignments of the major absorption bands identified in MOC composites.

\begin{tabular}{ll}
\hline \multicolumn{1}{c}{ Wavenumbers $\left(\mathbf{c m}^{-1}\right)$} & \multicolumn{1}{c}{ Assignment } \\
\hline 3695 & stretching $(v)$ vibration of $\mathrm{O}-\mathrm{H}$ in $\mathrm{Mg}(\mathrm{OH})_{2}$ \\
3677 & stretching $(v)$ vibration of $\mathrm{O}-\mathrm{H}$ in crystalline hydroxyl \\
3647 & stretching $(v)$ vibration of $\mathrm{O}-\mathrm{H}$ in silicate hydrates \\
$3611-3609,3585$ & stretching $(v)$ vibration of $\mathrm{H}-\mathrm{O}-\mathrm{H}$ in $\mathrm{MgCl}_{2} \cdot 8 \mathrm{H}_{2} \mathrm{O}$ \\
$3388-3391$ & stretching $(v)$ vibration of $\mathrm{H}-\mathrm{O}-\mathrm{H}$ in $\mathrm{H}_{2} \mathrm{O}$ \\
1644,1149 & bending $(\delta)$ vibration of $\mathrm{H}-\mathrm{O}-\mathrm{H}$ in $\mathrm{MgCl}_{2} \cdot 8 \mathrm{H}_{2} \mathrm{O}$ \\
1607 & stretching $(v)$ vibration of $\mathrm{C}=\mathrm{C}$ \\
1417,1446 & stretching $(v) \mathrm{C}=\mathrm{O}$ in $\mathrm{MgCO} 3$ \\
$1455-1423$ & stretching $(v) \mathrm{O}-\mathrm{H}$ in $\mathrm{C}-\mathrm{S}-\mathrm{H}$ and $\mathrm{M}-\mathrm{S}-\mathrm{H}$ phase, \\
$592-584$ & deformation $(\delta)$ and stretching $(v)$ lattice vibrations of \\
& Mg-Cl/Mg-O \\
$517-524,457$ & translation vibrations of $\mathrm{Mg} / \mathrm{Mg}-\mathrm{O}, \mathrm{Mg}-\mathrm{OH}$, and stretching $(v)$ \\
429 & vibration of O-Si-O in diatomite \\
414 & bending $(\delta)$ vibration of O-Si-O in diatomite \\
& vibrational modes of the lattice showing the $\mathrm{Mg}-\mathrm{O} / \mathrm{Mg}^{2+}$, \\
& O/O-Mg-O/O- $\mathrm{Mg}^{2+}-\mathrm{O}$ bonds \\
\hline
\end{tabular}

The basic structural parameters of 28-days samples are summarized in Table 5. The mean values from the measurement of 5 samples of each examined composites are presented together with their expanded combined uncertainties. The co-doping of the control matrix by GO and OMWCNTs resulted in the increased bulk density and specific density; this densification led to the significant drop in porosity, which was approx. $15.8 \%$ for MOCGO-OMWCNT-0.1 and 28.9\% for MOC-GO-OMWCNT-0.2, respectively. Quantitatively, the researched composites exhibited really low porosity; thus, their high mechanical strength and durability may be tanticipated. 
Table 5. Macro-structural parameters of 28 days matured composites.

\begin{tabular}{|c|c|c|c|}
\hline Composite & $\begin{array}{c}\text { Bulk Density } \\
\rho_{b} \\
\left(\mathbf{k g} \cdot \mathrm{m}^{-3}\right)\end{array}$ & $\begin{array}{c}\text { Specific Density } \\
\rho_{s} \\
\left(\mathrm{~kg} \cdot \mathrm{m}^{-3}\right)\end{array}$ & $\begin{array}{c}\text { Total Open Porosity } \\
\Psi \\
(\%)\end{array}$ \\
\hline MOC-REF & $1785 \pm 25$ & $1855 \pm 22$ & $3.8 \pm 0.1$ \\
\hline MOC-GO-OMWCNT-0.1 & $1801 \pm 25$ & $1861 \pm 22$ & $3.2 \pm 0.1$ \\
\hline MOC-GO-OMWCNT-0.2 & $1812 \pm 25$ & $1862 \pm 23$ & $2.7 \pm 0.1$ \\
\hline
\end{tabular}

In Table 6, the micro-structural parameters obtained by the mercury intrusion porosimetry (MIP) analysis are presented. The cumulative and incremental pore size distribution curves are displayed in Figures 9 and 10. MIP microstructural data gives evidence of the densifying and solidification effect of co-doping of MOC matrix by C-based nanoadditives. For all examined materials, the shape of the cumulative pore size distribution curves was almost similar. In the case of the incremental pore size distribution, the differences in pore size were more distinctive, especially in the pore diameter range from $0.015 \mu \mathrm{m}$ to $0.084 \mu \mathrm{m}$. These pores can be classified according to the IUPAC terminology [68] as macro-pores $(>50 \mathrm{~nm})$ and meso-pores $(2-50 \mathrm{~nm})$. Based on the pore size classification established in cement research, these pores are responsible for mechanical strength, permeability and, thus, frost resistance [69]. In this respect, one can simply estimate improvement in the mechanical performance and reduced water ingress by the co-doping of the MOC matrix.

Table 6. Microstructural parameters of 28 days matured composites.

\begin{tabular}{ccccc}
\hline Composite & $\begin{array}{c}\text { Average Pore } \\
\text { Diameter } \\
(\mu \mathbf{m})\end{array}$ & $\begin{array}{c}\text { Median Pore } \\
\text { Diameter } \\
(\mu \mathbf{m})\end{array}$ & $\begin{array}{c}\text { Total Pore Surface } \\
\text { Area } \\
\left(\mathbf{m}^{\mathbf{2}} \cdot \mathbf{g}^{-\mathbf{1}}\right)\end{array}$ & $\begin{array}{c}\text { Total Pore Volume } \\
\left(\mathbf{c m}^{\mathbf{3}} \cdot \mathbf{g}^{-\mathbf{1})}\right.\end{array}$ \\
\hline MOC-REF & 0.0113 & 0.0135 & 10.536 & 0.0298 \\
MOC-GO-OMWCNT-0.1 & 0.0105 & 0.0127 & 9.258 & 0.0240 \\
MOC-GO-OMWCNT-0.2 & 0.0103 & 0.0111 & 8.605 & 0.0238 \\
\hline
\end{tabular}

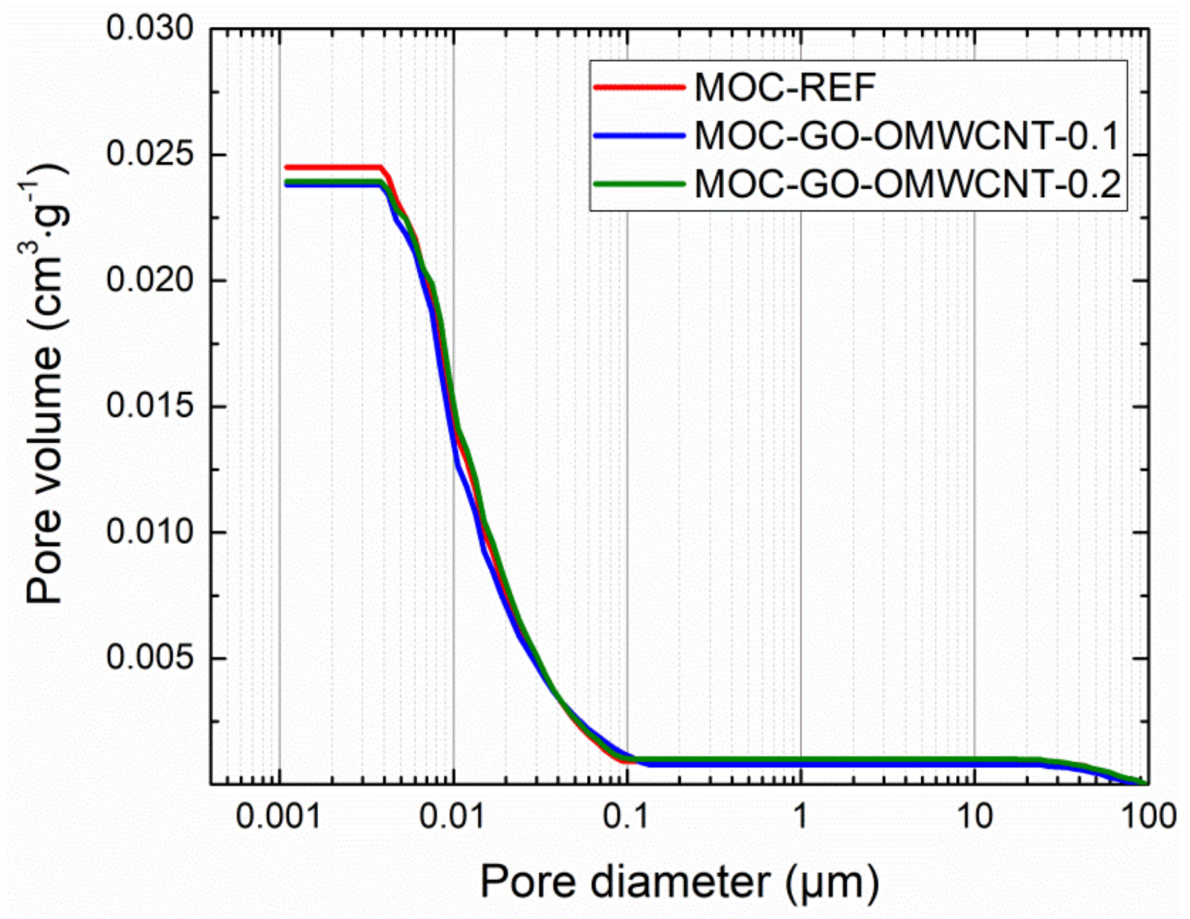

Figure 9. Pore size distribution—cumulative curves. 


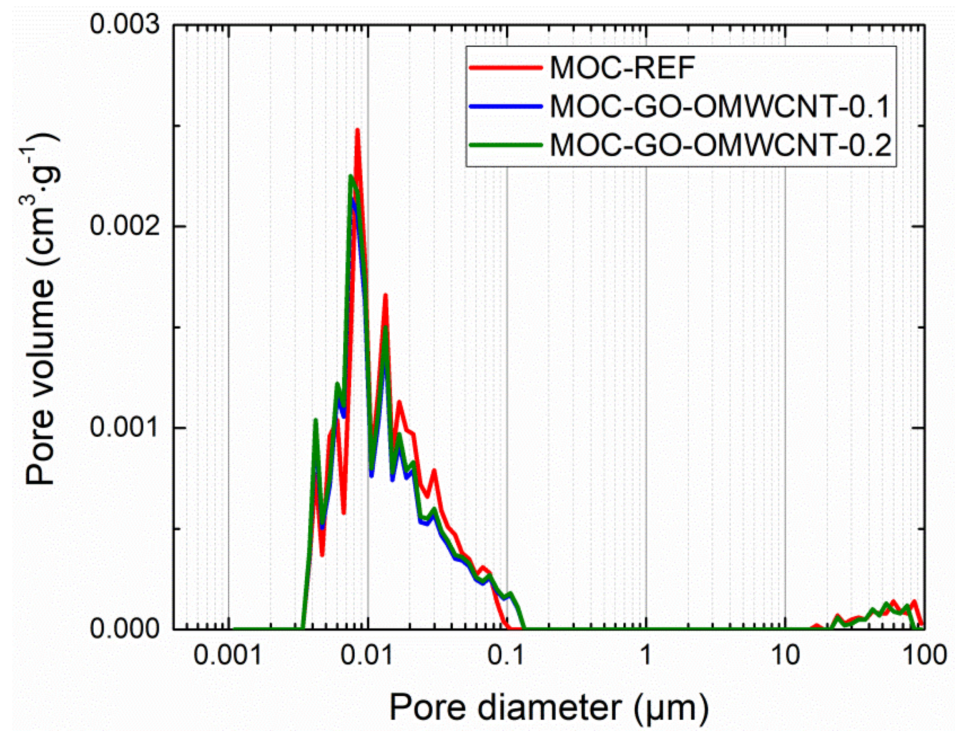

Figure 10. Pore size distribution-incremental curves.

The accessed mechanical parameters are presented in Figure 11. All materials exhibited high strength and stiffness that corresponded well with the nature of the MOC matrix $[70,71]$ and its low porosity. It is evident that the pore structure had a great impact on material's physical properties; thus, the lower the porosity and the smaller the pore number and the radii are the better the mechanical performance of the composite will be. As the compressive strength was affected by the nanoadditives to a low extent only, the combination of a high strength of graphene oxide [72,73], the bridging and interlocking effect of OMWCNTs [74], and the micro-pores filling resulted in a great improvement of flexural strength and toughening of the co-doped composites. The increase in the flexural strength was approx. $55.3 \%$ for MOC-GO-OMWCNTs- 0.1 and $92.1 \%$ for MOC-GO-OMWCNT-0.2. In this respect, one must consider that only low dosage of nano-dopants was used, and further enhancement in the mechanical performance can be anticipated in the case of a higher content of nanoadditives incorporated in the composite mixture.

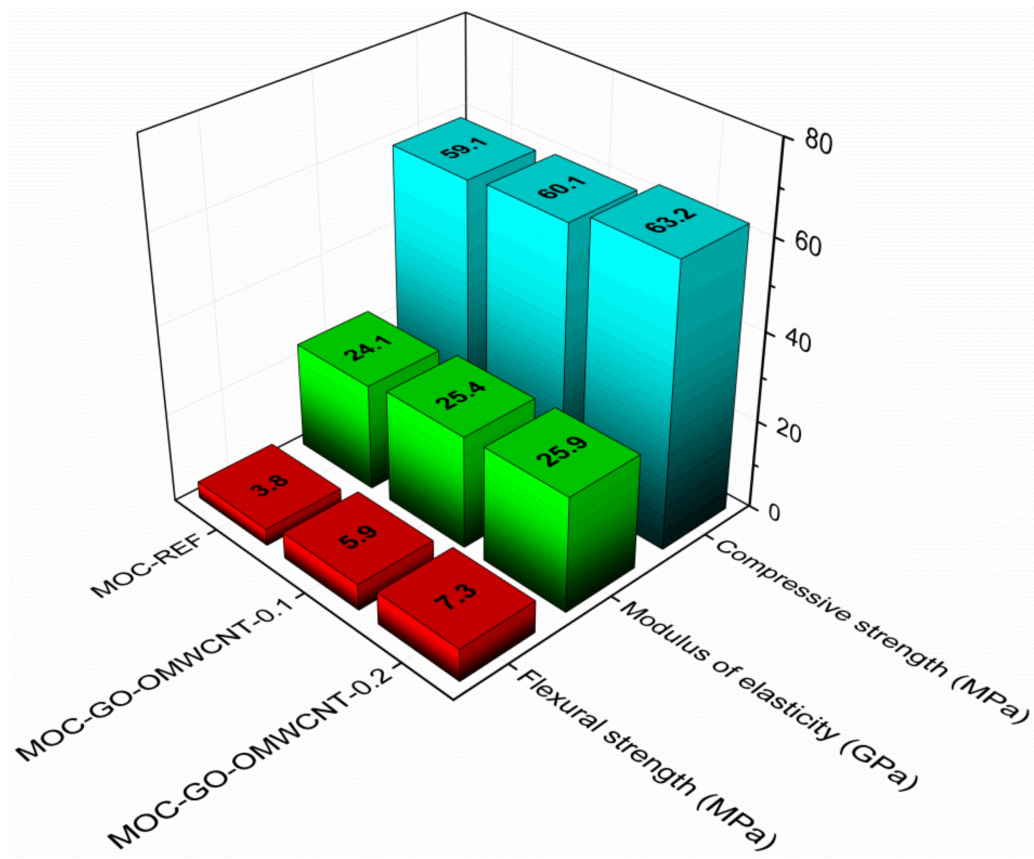

Figure 11. Mechanical properties of the 28-days matured samples. 
The water transport and storage properties obtained for the hardened composites are given in Table 7. In the comparison with the capillary porous materials [75-77], the water absorption coefficient and 24-h water absorption values were much lower; they were further reduced by the application of the nanoadditives. For example, the drop in $A_{w}$ was $\sim 24 \%$ for MOC-GO-OMWCNT-0.1 and 28\% for MOC-GO-OMWCNT-0.2. Accordingly, 24 -water absorption was reduced by $25 \%$ and $39 \%$, respectively. Similarly, as in the case of mechanical parameters, the reduction in water ingress was assigned to the drop in the volume of pores accessible for water, total reduced pore number and an average pore size. The limited wettability of the nano-doped composites gives presumption of their durability in terms of moisture-induced damage and allows one to classify the applied carbon-based dopants as water repellant admixtures for the MOC matrix. In combination with inorganic fillers, e.g., on active $\mathrm{SiO}_{2}$ basis, advanced, multifunctional MOC composites can be further designed and developed, meeting the technical, functional and durability criteria of the construction materials intended for specific application purposes.

Table 7. Hygric parameters of 28 days matured composites.

\begin{tabular}{|c|c|c|c|}
\hline Composite & $\begin{array}{c}\text { Water Absorption Coefficient } \\
A_{\mathrm{w}} \\
\left(\mathrm{kg} \cdot \mathrm{m}^{-2} \cdot \mathrm{s}^{-1 / 2}\right)\end{array}$ & $\begin{array}{c}\text { 24-h Water Absorption } \\
W \\
\left(\mathrm{~kg} \cdot \mathrm{m}^{-2}\right)\end{array}$ & $\begin{array}{c}\text { 24-h Water Absorption } \\
W_{\mathrm{a}} \\
(\mathrm{wt} . \%)\end{array}$ \\
\hline MOC-REF & $2.5 \times 10^{-3} \pm 6 \times 10^{-5}$ & $1.071 \pm 0.013$ & $0.9801 \pm 0.1$ \\
\hline MOC-GO-OMWCNT-0.1 & $1.9 \times 10^{-3} \pm 4 \times 10^{-5}$ & $0.803 \pm 0.009$ & $0.6313 \pm 0.1$ \\
\hline MOC-GO-OMWCNT-0.2 & $1.8 \times 10^{-3} \pm 4 \times 10^{-5}$ & $0.651 \pm 0.008$ & $0.5742 \pm 0.1$ \\
\hline
\end{tabular}

The thermal parameters measured on the transient hot disk technique principle are introduced in Table 8. Quantitatively, the values of the thermal conductivity were high, typical for dense inorganic materials, such as low porous concrete [78]. High thermal conductivity of MOC materials has already been reported in our previous studies, see, e.g., [79]. The assessed thermal properties represent results of two parallel effects: (i) dropped porosity and, thus, increased density that enhances itself for heat transport and storage, (ii) unique properties of carbon-based nanoadditives that, in respect to their morphology, size and defects [80], exhibit high thermal conductivity and heat capacity [81,82]; they are temperature dependent and show changes in dimensionality [83]. Although it is impossible to distinguish which effect was the dominant in enhancement of the analyzed thermal parameters, co-doping nanoadditives have served as controlling agents of heat transport and storage, respectively. This might find application in MOC composites with low heat conductive phase change materials that could be effectively heated by the bridging effect of OMWCNTs and dispersed GO particles.

Table 8. Heat transport and storage parameters of 28 days matured composites.

\begin{tabular}{|c|c|c|c|}
\hline Composite & $\begin{array}{c}\text { Thermal Conductivity } \\
\lambda \\
\left(\mathrm{W} \cdot \mathrm{m}^{-1} \cdot \mathrm{K}^{-1}\right)\end{array}$ & $\begin{array}{l}\text { Thermal Diffusivity } \\
\qquad \begin{array}{l}a \\
\times 10^{-6}\left(\mathrm{~m}^{2} \cdot \mathrm{s}^{-1}\right)\end{array}\end{array}$ & $\begin{array}{c}\text { Volumetric Heat Capacity } \\
\qquad c_{\mathrm{V}} \\
\times 10^{6}\left(\mathrm{~J} \cdot \mathrm{m}^{-3} \cdot \mathrm{K}^{-1}\right)\end{array}$ \\
\hline MOC-REF & $1.276 \pm 0.029$ & $0.493 \pm 0.013$ & $2.588 \pm 0.067$ \\
\hline MOC-GO-OMWCNT-0.1 & $1.322 \pm 0.030$ & $0.494 \pm 0.013$ & $2.675 \pm 0.070$ \\
\hline MOC-GO-OMWCNT-0.2 & $1.334 \pm 0.031$ & $0.474 \pm 0.012$ & $2.815 \pm 0.073$ \\
\hline
\end{tabular}

\section{Conclusions}

In this research, the combined effect of oxidized 1D and 2D carbon nanoadditives on the MOC Phase 5 was studied. The following advanced findings of the analysis of the 28-days hardened samples were highlighted:

(i). the micro- and macro-structural parameters analyses showed the base of the enhancement caused by the carbon-based nanoadditives that significantly decreased the 
porosity, which was reduced by $\sim 15.8 \%$ for MOC-GO-OMWCNT-0.1 and $~ 28.9 \%$ for MOC-GO-OMWCNT-0.2;

(ii). the great drop of porosity led to the increase in the mechanical parameters, where the flexural strength values increased by $55.3 \%$ and $92.1 \%$ for the samples containing 0.1 and 0.2 wt. \% of each nanoadditive, respectively;

(iii). as the volume of pores decreased due to their filling and interlocking with the nanoadditives, the water transport and storage properties were significantly lowered; thus, the improved water resistance of the MOC matrix can be anticipated-this effect of the nanodopants is crucial for the MOC-based composites, which are usually considered as materials with very poor water resistance;

(iv). the materials thermal conductivity was quite high due to the decreased porosity, but also as a result of adapting the thermal conductivities of the used GO and OMWCNTs, which are generally very high.

Based on the summarized results it was concluded, the used nanoadditives have significant potential in the field of design and the development of advanced and multifunctional MOC-based composites. However, the homogenization and ideal dispersion of the nanodopants must be improved in order to get even greater enhancement of the composite properties.

Author Contributions: Conceptualization, O.J., M.P. and Z.P.; investigation, A.-M.L., J.S., I.F., M.L., M.P., A.P., Š.M. and M.Z.; data curation, O.J., M.P., J.S., I.F., A.P., Š.M., M.Z. and Z.P.; writing—original draft preparation, A.-M.L., O.J., M.P. and Z.P.; writing - review and editing, O.J. and Z.P.; supervision, O.J., M.P. and Z.P.; project administration, O.J. and M.P.; funding acquisition, O.J. and Z.P. All authors have read and agreed to the published version of the manuscript.

Funding: This research was funded by the Czech Science Foundation, grant NO 20-01866S, and by the Grant Agency of the Czech Technical University in Prague, grant No SGS20/153/OHK1/3T/11. This work was supported also by the grant of Specific university research—grant MSMT No. 20-SVV/2021.

Institutional Review Board Statement: Not applicable.

Informed Consent Statement: Not applicable.

Data Availability Statement: The data presented in this study are available on request from the corresponding author. The data are not publicly available due to privacy.

Acknowledgments: The technical support in the mechanical parameters testing received from Pavel Košata from the Czech Technical University in Prague is greatly acknowledged.

Conflicts of Interest: The authors declare no conflict of interest.

\section{References}

1. Sorel, S. On a new magnesium cement. CR Acad. Sci. 1867, 65, 102-104.

2. Li, K.; Wang, Y.; Yao, N.; Zhang, A. Recent progress of magnesium oxychloride cement: Manufacture, curing, structure and performance. Constr. Build. Mater. 2020, 255, 119381. [CrossRef]

3. Kastiukas, G.; Ruan, S.; Unluer, C.; Liang, S.; Zhou, X. Environmental Assessment of Magnesium Oxychloride Cement Samples: A Case Study in Europe. Sustainability 2019, 11, 6957. [CrossRef]

4. Beaudoin, J.J.; Ramachandran, V.S. Strength development in magnesium oxychloride and other cements. Cem. Concr. Res. 1975, 5, 617-630. [CrossRef]

5. Góchez, R.; Wambaugh, J.; Rochner, B.; Kitchens, C. Kinetic study of the magnesium oxychloride cement cure reaction. J. Mater. Sci. 2017, 52, 7637-7646. [CrossRef]

6. Montle, J.; Mayhan, K. The role of magnesium oxychloride as a fire-resistive material. Fire Technol. 1974, 10, 201-210. [CrossRef]

7. Jirickova, A.; Lojka, M.; Lauermannova, A.M.; Antonacik, F.; Sedmidubsky, D.; Pavlikova, M.; Zaleska, M.; Pavlik, Z.; Jankovsky, O. Synthesis, Structure, and Thermal Stability of Magnesium Oxychloride 5Mg(OH)(2).MgCl2.8H(2)O. Appl. Sci. 2020, $10,1683$. [CrossRef]

8. Lauermannová, A.-M.; Lojka, M.; Jankovský, O.; Faltysová, I.; Pavlíková, M.; Pivák, A.; Záleská, M.; Pavlík, Z. High-performance magnesium oxychloride composites with silica sand and diatomite. J. Mater. Res. Technol. 2021, 11, 957-969. [CrossRef]

9. Chau, C.K.; Chan, J.; Li, Z. Influences of fly ash on magnesium oxychloride mortar. Cem. Concr. Compos. 2009, 31, 250-254. [CrossRef] 
10. Li, Y.; Yu, H.; Zheng, L.; Wen, J.; Wu, C.; Tan, Y. Compressive strength of fly ash magnesium oxychloride cement containing granite wastes. Constr. Build. Mater. 2013, 38, 1-7. [CrossRef]

11. He, P.; Poon, C.S.; Tsang, D.C.W. Comparison of glass powder and pulverized fuel ash for improving the water resistance of magnesium oxychloride cement. Cem. Concr. Compos. 2018, 86, 98-109. [CrossRef]

12. Zhou, X.; Li, Z. Light-weight wood-magnesium oxychloride cement composite building products made by extrusion. Constr. Build. Mater. 2012, 27, 382-389. [CrossRef]

13. He, P.; Hossain, M.U.; Poon, C.S.; Tsang, D.C.W. Mechanical, durability and environmental aspects of magnesium oxychloride cement boards incorporating waste wood. J. Clean. Prod. 2019, 207, 391-399. [CrossRef]

14. Lauermannová, A.-M.; Faltysová, I.; Lojka, M.; Antončík, F.; Sedmidubský, D.; Pavlík, Z.; Pavlíková, M.; Záleská, M.; Pivák, A.; Jankovský, O. Regolith-based magnesium oxychloride composites doped by graphene: Novel high-performance building materials for lunar constructions. FlatChem 2021, 26, 100234. [CrossRef]

15. Fediuk, R.; Lesovik, V.; Mochalov, A.; Otsokov, K.; Lashina, I.; Timokhin, R. Composite binders for concrete of protective structures. Mag. Civil Eng. 2018, 6, 208-218.

16. Li, Z.; Chau, C. Influence of molar ratios on properties of magnesium oxychloride cement. Cem. Concr. Res. 2007, 37, 866-870. [CrossRef]

17. $\mathrm{Ba}, \mathrm{H}$.; Guan, $\mathrm{H}$. Influence of $\mathrm{MgO} / \mathrm{MgCl} 2$ molar ratio on phase stability of magnesium oxychloride cement. J. Wuhan Univ. Technol. Mater. Sci. Ed. 2009, 24, 476-481. [CrossRef]

18. Liu, Z.; Wang, S.; Huang, J.; Wei, Z.; Guan, B.; Fang, J. Experimental investigation on the properties and microstructure of magnesium oxychloride cement prepared with caustic magnesite and dolomite. Constr. Build. Mater. 2015, 85, 247-255. [CrossRef]

19. Chau, C.K.; Li, Z. Microstructures of magnesium oxychloride Sorel cement. Adv. Cem. Res. 2008, 20, 85-92. [CrossRef]

20. Walling, S.A.; Provis, J.L. Magnesia-Based Cements: A Journey of 150 Years, and Cements for the Future? Chem. Rev. 2016, 116, 4170-4204. [CrossRef]

21. Jankovský, O.; Lojka, M.; Lauermannová, A.-M.; Antončík, F.; Pavlíková, M.; Pavlík, Z.; Sedmidubský, D. Carbon Dioxide Uptake by MOC-Based Materials. Appl. Sci. 2020, 10, 2254. [CrossRef]

22. Zhang, F.-J.; Sun, X.-Y.; Li, X.; Zhang, D.; Xie, W.-J.; Liu, J.; Oh, W.-C. Study on Water Resistance of Environmentally Friendly Magnesium Oxychloride Cement for Waste Wood Solidification. J. Korean Ceram. Soc. 2018, 55, 446-451. [CrossRef]

23. Zhang, X.; Ge, S.; Wang, H.; Chen, R. Effect of 5-phase seed crystal on the mechanical properties and microstructure of magnesium oxychloride cement. Constr. Build. Mater. 2017, 150, 409-417. [CrossRef]

24. Sorre, C.A.; Armstron, C.R. Reactions and Equilibria in Magnesium Oxychloride Cements. J. Am. Ceram. Soc. 1976, 59, 51-54. [CrossRef]

25. Robinson, W.; Waggaman, W. Basic magnesium chlorides. J. Phys. Chem. 2002, 13, 673-678. [CrossRef]

26. Matkovic, B.; Young, J. Microstructure of magnesium oxychloride cements. Nat. Phys. Sci. 1973, 246, 79. [CrossRef]

27. Gong, W.; Yu, H.; Ma, H.; Qiao, H.; Chen, G. Study on corrosion and anticorrosion of rebar in magnesium oxychloride cement concrete. Emerg. Mater. Res. 2019, 8, 94-104. [CrossRef]

28. Amran, M.; Fediuk, R.; Vatin, N.; Huei Lee, Y.; Murali, G.; Ozbakkaloglu, T.; Klyuev, S.; Alabduljabber, H. Fibre-Reinforced Foamed Concretes: A Review. Materials 2020, 13, 4323. [CrossRef]

29. Li, Y.; Li, Z.; Pei, H.; Yu, H. The influence of $\mathrm{FeSO}_{4}$ and $\mathrm{KH}_{2} \mathrm{PO}_{4}$ on the performance of magnesium oxychloride cement. Constr. Build. Mater. 2016, 102, 233-238. [CrossRef]

30. Guan, B.; Tian, H.; Ding, D.; Wu, J.; Xiong, R.; Xu, A.; Chen, H. Effect of Citric Acid on the Time-Dependent Rheological Properties of Magnesium Oxychloride Cement. J. Mater. Civ. Eng. 2018, 30, 04018275. [CrossRef]

31. Chen, X.; Zhang, T.; Bi, W.; Cheeseman, C.R. Effect of tartaric acid and phosphoric acid on the water resistance of magnesium oxychloride (MOC) cement. Constr. Build. Mater. 2019, 213, 528-536. [CrossRef]

32. Wu, C.; Chen, W.; Zhang, H.; Yu, H.; Zhang, W.; Jiang, N.; Liu, L. The hydration mechanism and performance of Modified magnesium oxysulfate cement by tartaric acid. Constr. Build. Mater. 2017, 144, 516-524. [CrossRef]

33. Wu, C.; Zhang, H.; Yu, H. The effects of alumina-leached coal fly ash residue on magnesium oxychloride cement. Adv. Cem. Res. 2013, 25, 254-261. [CrossRef]

34. He, P.; Poon, C.S.; Tsang, D.C.W. Using incinerated sewage sludge ash to improve the water resistance of magnesium oxychloride cement (MOC). Constr. Build. Mater. 2017, 147, 519-524. [CrossRef]

35. Lee, C.; Wei, X.; Kysar, J.W.; Hone, J. Measurement of the Elastic Properties and Intrinsic Strength of Monolayer Graphene. Science 2008, 321, 385-388. [CrossRef]

36. Novoselov, K.S.; Geim, A. The rise of graphene. J. Nat. Mater. 2007, 6, 183-191.

37. Falkovsky, L.A. Optical properties of graphene. J. Phys. Conf. Ser. 2008, 129, 012004. [CrossRef]

38. Jankovský, O.; Lojka, M.; Luxa, J.; Sedmidubský, D.; Pumera, M.; Sofer, Z. Introduction of sulfur to graphene oxide by FriedelCrafts reaction. FlatChem 2017, 6, 28-36. [CrossRef]

39. Panchakarla, L.; Subrahmanyam, K.; Saha, S.; Govindaraj, A.; Krishnamurthy, H.; Waghmare, U.; Rao, C. Synthesis, structure, and properties of boron-and nitrogen-doped graphene. Adv. Mater. 2009, 21, 4726-4730. [CrossRef]

40. Qu, L.; Liu, Y.; Baek, J.-B.; Dai, L. Nitrogen-doped graphene as efficient metal-free electrocatalyst for oxygen reduction in fuel cells. ACS Nano 2010, 4, 1321-1326. [CrossRef] 
41. Wu, J.; Xie, L.; Li, Y.; Wang, H.; Ouyang, Y.; Guo, J.; Dai, H. Controlled chlorine plasma reaction for noninvasive graphene doping. J. Am. Chem. Soc. 2011, 133, 19668-19671. [CrossRef]

42. Yang, Z.; Yao, Z.; Li, G.; Fang, G.; Nie, H.; Liu, Z.; Zhou, X.; Chen, X.A.; Huang, S. Sulfur-doped graphene as an efficient metal-free cathode catalyst for oxygen reduction. ACS Nano 2011, 6, 205-211. [CrossRef]

43. Zhang, C.; Mahmood, N.; Yin, H.; Liu, F.; Hou, Y. Synthesis of Phosphorus-Doped Graphene and its Multifunctional Applications for Oxygen Reduction Reaction and Lithium Ion Batteries. Adv. Mater. 2013, 25, 4932-4937. [CrossRef] [PubMed]

44. Fu, Q.; Gao, B.; Dou, H.; Hao, L.; Lu, X.; Sun, K.; Jiang, J.; Zhang, X. Novel non-covalent sulfonated multiwalled carbon nanotubes from p-toluenesulfonic acid/glucose doped polypyrrole for electrochemical capacitors. Synth. Met. 2011, 161, 373-378. [CrossRef]

45. Ferreira, F.V.; Francisco, W.; Menezes, B.R.C.D.; Cividanes, L.D.S.; Coutinho, A.D.R.; Thim, G.P. Carbon nanotube functionalized with dodecylamine for the effective dispersion in solvents. Appl. Surf. Sci. 2015, 357, 2154-2159. [CrossRef]

46. Cividanes, L.D.S.; Simonetti, E.A.N.; de Oliveira, J.I.S.; Serra, A.A.; Carlos de Souza Barboza, J.; Thim, G.P. The sonication effect on CNT-epoxy composites finally clarified. Polym. Compos. 2017, 38, 1964-1973. [CrossRef]

47. Mohamed, A.; Anas, A.K.; Bakar, S.A.; Ardyani, T.; Zin, W.M.W.; Ibrahim, S.; Sagisaka, M.; Brown, P.; Eastoe, J. Enhanced dispersion of multiwall carbon nanotubes in natural rubber latex nanocomposites by surfactants bearing phenyl groups. J. Colloid Interface Sci. 2015, 455, 179-187. [CrossRef] [PubMed]

48. Balasubramanian, K.; Burghard, M. Chemically Functionalized Carbon Nanotubes. Small 2005, 1, 180-192. [CrossRef]

49. Parveen, S.; Rana, S.; Fangueiro, R. A review on nanomaterial dispersion, microstructure, and mechanical properties of carbon nanotube and nanofiber reinforced cementitious composites. J. Nanomater. 2013, 2013, 80. [CrossRef]

50. Jankovský, O.; Jiř́čková, A.; Luxa, J.; Sedmidubský, D.; Pumera, M.; Sofer, Z. Fast Synthesis of Highly Oxidized Graphene Oxide ChemistrySelect 2017, 2, 9000-9006. [CrossRef]

51. Rosca, I.D.; Watari, F.; Uo, M.; Akasaka, T. Oxidation of multiwalled carbon nanotubes by nitric acid. Carbon 2005, 43, 3124-3131 [CrossRef]

52. Korayem, A.H.; Tourani, N.; Zakertabrizi, M.; Sabziparvar, A.M.; Duan, W.H. A review of dispersion of nanoparticles in cementitious matrices: Nanoparticle geometry perspective. Constr. Build. Mater. 2017, 153, 346-357. [CrossRef]

53. Chuah, S.; Pan, Z.; Sanjayan, J.G.; Wang, C.M.; Duan, W.H. Nano reinforced cement and concrete composites and new perspective from graphene oxide. Constr. Build. Mater. 2014, 73, 113-124. [CrossRef]

54. Lauermannová, A.-M.; Lojka, M.; Sklenka, J.; Záleská, M.; Pavlíková, M.; Pivák, A.; Pavlík, Z.; Jankovský, O. Magnesium oxychloride-graphene composites: Towards high strength and water resistant materials for construction industry. FlatChem 2021, 29, 100284. [CrossRef]

55. Lojka, M.; Lauermannová, A.-M.; Sedmidubský, D.; Pavlíková, M.; Záleská, M.; Pavlík, Z.; Pivák, A.; Jankovský, O. Magnesium Oxychloride Cement Composites with MWCNT for the Construction Applications. Materials 2021, 14, 484. [CrossRef] [PubMed]

56. Kolev, S.; Petkov, P.S.; Rangelov, M.; Vayssilov, G.N. Ab Initio Molecular Dynamics of Na+ and Mg2+ Countercations at the Backbone of RNA in Water Solution. ACS Chem. Biol. 2013, 8, 1576-1589. [CrossRef] [PubMed]

57. He, H.; Klinowski, J.; Forster, M.; Lerf, A. A new structural model for graphite oxide. Chem. Phys. Lett. 1998, 287, 53-56. [CrossRef]

58. Park, S.; Lee, K.-S.; Bozoklu, G.; Cai, W.; Nguyen, S.T.; Ruoff, R.S. Graphene Oxide Papers Modified by Divalent Ions-Enhancing Mechanical Properties via Chemical Cross-Linking. ACS Nano 2008, 2, 572-578. [CrossRef]

59. Srivastava, S. Sorption Of Divalent Metal Ions From Aqueous Solution By Oxidized carbon Nanotubes And Nanocages: A Review. Adv. Mater. Lett. 2013, 4, 2-8. [CrossRef]

60. European Committee for Standardization. EN 1015-10, Methods of Test for Mortar for Masonry—Part 10: Determination of Dry Bulk Density of Hardened 676 Mortar; European Committee for Standardization: Brussels, Belgium, 1999.

61. Záleská, M.; Pavlík, Z.; Ćítek, D.; Jankovský, O.; Pavlíková, M. Eco-friendly concrete with scrap-tyre-rubber-based aggregateProperties and thermal stability. Constr. Build. Mater. 2019, 225, 709-722. [CrossRef]

62. European Committee for Standardization. EN 1015-11: Methods of Test for Mortar for Masonry-Part 10: Determination of Flexural and Compressive Strength 678 of Hardened Mortar; European Committee for Standardization: Brussels, Belgium, 1999.

63. European Committee for Standardization. EN 1015-18: Methods of Test for Mortar for Masonry -Part 18: Determination of Water Absorption Coefficient Due to Capillary Action of Hardened Mortar; European Committee for Standardization: Brussels, Belgium, 2002.

64. Bandara, N.; Esparza, Y.; Wu, J. Graphite Oxide Improves Adhesion and Water Resistance of Canola Protein-Graphite Oxide Hybrid Adhesive. Sci. Rep. 2017, 7, 11538. [CrossRef] [PubMed]

65. Záleská, M.; Pavlíková, M.; Pivák, A.; Marušiak, Š.; Jankovský, O.; Lauermannová, A.-M.; Lojka, M.; Antončík, F.; Pavlík, Z. MOC Doped with Graphene Nanoplatelets: The Influence of the Mixture Preparation Technology on Its Properties. Materials 2021, 14, 1450. [CrossRef] [PubMed]

66. Guo, Y.; Zhang, Y.; Soe, K.; Hutchison, W.D.; Timmers, H.; Poblete, M.R. Effect of fly ash on mechanical properties of magnesium oxychloride cement under water attack. Struct. Concr. 2020, 21, 1181-1199. [CrossRef]

67. Chukanov, N.V. Infrared Spectra of Mineral Species: Extended Library; Springer Science \& Business Media: Berlin/Heidelberg, Germany, 2013.

68. Everett, D.H. Manual of Symbols and Terminology for Physicochemical Quantities and Units, Appendix II: Definitions, Terminology and Symbols in Colloid and Surface Chemistry. Pure Appl. Chem. 1972, 31, 577-638. [CrossRef]

69. Adilhodzhaev, A.I.; Kadyrov, I.; Umarov, K. Research of porosity of a cement stone with a zeolite containing filler and a superplasticstificator. J. Tashkent Inst. Railw. Eng. 2020, 16, 15-22. 
70. Guo, Y.; Zhang, Y.X.; Soe, K.; Wuhrer, R.; Hutchison, W.D.; Timmers, H. Development of magnesium oxychloride cement with enhanced water resistance by adding silica fume and hybrid fly ash-silica fume. J. Clean. Prod. 2021, 313, 127682. [CrossRef]

71. Zgueb, R.; Brichni, A.; Yacoubi, N. Improvement of the thermal properties of Sorel cements by polyvinyl acetate: Consequences on physical and mechanical properties. Energy Build. 2018, 169, 1-8. [CrossRef]

72. Prabavathy, S.; Jeyasubramanian, K.; Prasanth, S.; Hikku, G.S.; Robert, R.B.J. Enhancement in behavioral properties of cement mortar cubes admixed with reduced graphene oxide. J. Build. Eng. 2020, 28, 101082. [CrossRef]

73. Zhou, C.; Li, F.; Hu, J.; Ren, M.; Wei, J.; Yu, Q. Enhanced mechanical properties of cement paste by hybrid graphene oxide/carbon nanotubes. Constr. Build. Mater. 2017, 134, 336-345. [CrossRef]

74. Gong, J.; Lin, L.; Fan, S. Modification of cementitious composites with graphene oxide and carbon nanotubes. SN Appl. Sci. 2020, 2, 1622. [CrossRef]

75. Feng, C.; Guimarães, A.S.; Ramos, N.; Sun, L.; Gawin, D.; Konca, P.; Hall, C.; Zhao, J.; Hirsch, H.; Grunewald, J.; et al. Hygric properties of porous building materials (VI): A round robin campaign. Build. Environ. 2020, 185, 107242. [CrossRef]

76. Ma, Z.; Tang, Q.; Wu, H.; Xu, J.; Liang, C. Mechanical properties and water absorption of cement composites with various fineness and contents of waste brick powder from C\&D waste. Cem. Concr. Compos. 2020, 114, 103758. [CrossRef]

77. Vyšvařil, M.; Pavlíková, M.; Záleská, M.; Pivák, A.; Žižlavský, T.; Rovnaníková, P.; Bayer, P.; Pavlík, Z. Non-hydrophobized perlite renders for repair and thermal insulation purposes: Influence of different binders on their properties and durability. Constr. Build. Mater. 2020, 263, 120617. [CrossRef]

78. Demirboğa, R. Thermal conductivity and compressive strength of concrete incorporation with mineral admixtures. Build. Environ. 2007, 42, 2467-2471. [CrossRef]

79. Pivák, A.; Pavlíková, M.; Záleská, M.; Lojka, M.; Jankovský, O.; Pavlík, Z. Magnesium Oxychloride Cement Composites with Silica Filler and Coal Fly Ash Admixture. Materials 2020, 13, 2537. [CrossRef] [PubMed]

80. Bagatskii, M.I.; Jeżowski, A.; Szewczyk, D.; Sumarokov, V.V.; Barabashko, M.S.; Kuznetsov, V.L.; Moseenkov, S.I.; Ponomarev, A.N. Size effects in the heat capacity of modified MWCNTs. Therm. Sci. Eng. Prog. 2021, 26, 101097. [CrossRef]

81. Gardea, F.; Lagoudas, D.C. Characterization of electrical and thermal properties of carbon nanotube/epoxy composites. Compos. Part B Eng. 2014, 56, 611-620. [CrossRef]

82. Miranda, A.; Barekar, N.; McKay, B.J. MWCNTs and their use in Al-MMCs for ultra-high thermal conductivity applications: A review. J. Alloy. Compd. 2019, 774, 820-840. [CrossRef]

83. Masarapu, C.; Henry, L.L.; Wei, B. Specific heat of aligned multiwalled carbon nanotubes. Nanotechnology 2005, 16, 1490-1494. [CrossRef] 